\title{
An accumulation of turtle eggs with embryos from the Campanian (Upper Cretaceous) Judith River Formation of Montana
}

\section{Authors: Daniel R. Lawver and Frankie D. Jackson}

NOTICE: this is the author's version of a work that was accepted for publication in Cretaceous Research. Changes resulting from the publishing process, such as peer review, editing, corrections, structural formatting, and other quality control mechanisms may not be reflected in this document. Changes may have been made to this work since it was submitted for publication. A definitive version was subsequently published in Cretaceous Research VOL\# 69, (January 2017) DOI\# 10.1016/i.cretres.2016.08.012

Lawver, Daniel R, and Frankie D Jackson. "An accumulation of turtle eggs with embryos from the Campanian (Upper Cretaceous) Judith River Formation of Montana." Cretaceous Research 69 (January 2017): 90-99. DOI: 10.1016/j.cretres.2016.08.012.

Made available through Montana State University's ScholarWorks scholarworks. montana.edu 


\title{
An accumulation of turtle eggs with embryos from the Campanian (Upper Cretaceous) Judith River Formation of Montana
}

\author{
Daniel R. Lawver a, b, *, Frankie D. Jackson ${ }^{\mathrm{a}}$ \\ a Department of Earth Sciences, Montana State University, Bozeman, MT, 59717, USA \\ ${ }^{\mathrm{b}}$ Museum of the Rockies, Bozeman, MT, 59717, USA
}

\begin{abstract}
A B S T R A C T
A weathered accumulation of turtle eggs, interpreted as remnants of a single clutch composed of at least 16 turtle eggs (MOR 710) from the Campanian (Upper Cretaceous) Judith River Formation of northcentral Montana, USA, represents a new oospecies Testudoolithus zelenitskyae. This ootaxon is diagnosed by the following unique combination of characters: spherical eggs $34-39 \mathrm{~mm}$ in diameter, 660 $-760 \mu \mathrm{m}$ thick eggshell, shell unit height-to-width ratio of 3.15:1-5.5:1, and domed shell units. Estimated egg mass indicates that the egg-laying adult likely possessed a carapace $35.0-54.4 \mathrm{~cm}$ in length. Similarities between $T$. zelenitskyae oosp. nov. and Adocus sp. eggs, along with comparable body size, suggest that this taxon might have produced MOR 710. One egg exhibits abnormal multilayered eggshell, likely resulting from prolonged egg retention by the female turtle. At least five of these eggs, including the multilayered specimen, preserve embryonic remains that demonstrate a late stage of embryonic development. This suggests that death occurred just prior to hatching.
\end{abstract}

\section{Introduction}

Fossil turtle egg clutches, gravid adults, and turtle embryos are relatively rare in the rock record when compared to dinosaurian specimens (Lawver and Jackson, 2014). Jackson et al. (2008) report an in situ turtle egg clutch preserving 23 spherical eggs in three superimposed layers from the Albian (Lower Cretaceous) deposits of Tiantai basin of Zhejiang, China. Zelenitsky et al. (2008) describe a clutch of 26 eggs from the Campanian (Upper Cretaceous) Oldman Formation of Alberta, Canada and estimated that a female with carapace length of $49.5 \mathrm{~cm}$ produced the clutch. A possible tortoise clutch containing at least five eggs comes from the Pliocene Apolakkia Formation of Rhodes, Greece (Mueller-Töwe et al., 2011), and fossil egg clutches from the Pleistocene of Lord Howe Island, Australia are tentatively assigned to the stem turtle, Meiolania platyceps (Anderson, 1925; Gaffney, 1996; Lawver and Jackson, in press).

In contrast to these turtle clutches, fossil gravid turtles provide definitive assignment of eggs to a specific taxon. A gravid turtle and a turtle clutch from the Upper Cretaceous Dinosaur Park and Oldman formations, respectively, show similar eggshell microstructure. Zelenitsky et al. (2008) conclude that both are referable to Adocus sp. Likewise, Knell et al. (2011) report portions of two eggs within a gravid Adocus sp. from the Campanian (Upper Cretaceous) Kaiparowits Formation of Utah. Additionally, an undescribed gravid Basilemys variolosa from the Dinosaur Park Formation of Alberta, Canada preserves at least three eggs that were discovered when the specimen was inadvertently damaged (Braman and Brinkman, 2009). Finally, a eurysternid specimen from the Upper Jurassic of Solnhofen in Germany contains spherical objects that Joyce and Zelenitsky (2002) interpreted as highly altered eggs.

Fossil turtle embryos are known from North America (Zelenitsky, 1995; Clouse, 2001; Jackson and Schmitt, 2008; Zelenitsky et al., 2008; McGee, 2012), Asia (Mikhailov et al., 1994; Cohen et al., 1995; Fang et al., 2009), and Europe (Hemprich, 1932). Although, morphological analysis of these specimens could assist in determining their taxonomic affinity, only one specimen has been investigated. Using computerized tomography (micro-CT) McGee (2012) confirmed that Adocus sp. produced the clutch from the Oldman Formation, thereby agreeing with the previous identification of Zelenitsky et al. (2008).

Although rare, fossil turtle clutches, gravid females, and embryonic remains provide important information about the 
evolution of turtle reproduction and paleoecology. Here, we describe a weathered accumulation of turtle eggs (some containing embryos), which we interpret as remnants of a single clutch. The egg accumulation is from the Campanian strata of the Judith River Formation of north-central Montana, USA. Jackson and Schmitt (2008) briefly report the microstructure of the multilayered egg from this clutch when establishing criteria for recognition of egg abnormalities in the fossil record. However, a detailed description of the clutch was beyond the scope of their paper. Jackson and Schmitt (2008) simply referred to this egg as MOR 710, whereas here it is assigned as MOR 710B. We describe this weathered clutch, assign the eggs to parataxonomy, and discuss the implications for the evolution of turtle reproductive biology.

Institutional Abbreviations: AM, Australian Museum, Sydney, New South Wales, Australia; BMNH, The Natural History Museum, London, United Kingdom; HEC, Hirsch Eggshell Catalogue, University of Colorado, Boulder, Colorado, U.S.A; IVPP, Institute of Vertebrate Paleontology and Paleoanthropology, Beijing, China; LBA, L. Barry Albright field number; $\mathrm{MCZ}$, Museum of Comparative Zoology, Cambridge, Massachusetts, U.S.A; MOR, Museum of the Rockies, Bozeman, Montana, U.S.A; NHMU, Natural History Museum of Utah, Salt Lake City, Utah, U.S.A; TMP, Royal Tyrrell Museum of Paleontology, Alberta, Canada; UCM, University of Colorado Museum, Boulder, Colorado, U.S.A; ZMNH, Zhejiang Museum of Natural History, Hangzhou, Zhejiang Province, China.

\section{Materials and methods}

The fossil turtle eggs studied are housed at the Museum of the Rockies (MOR) in Bozeman, Montana. Two multilayered eggshells were removed from an egg from MOR 710. One was etched with hydrochloric acid for about five seconds in order to better reveal the fine crystalline structure. Histological radial sections were made through eggshell fragments from both normal eggs (MOR 710A, C), the multilayered specimen (MOR 710B), and an embryonic costal element labeled MOR 710:EB 3 (the exact location of the section is indeterminate). Additional eggshell thin sections (MOR 710:ES 1-3) came from unspecified eggs within the clutch. Histological procedures follow Lamm (2013). Eggshell fragments were mounted on an aluminum stub, coated with $10 \mathrm{~nm}$ of gold, and imaged under a JEOL JSM-6100 scanning electron microscope (SEM) at $10 \mathrm{kV}$. Images included the inner surface and radial cross sections of the eggshell. Photomicrographs of histological sections of eggshell and bone were taken with a Nikon Digital Sight DS-5Mc camera and microstructural features were measured with the image analysis software ImageJ (Rasband, 1997; http://imagej.nih. gov/ij/). Assessment of potential diagenetic alteration of the eggshell included a Nikon eclipse 50i microscope equipped with cathodoluminescence $(\mathrm{CL})$. Egg mass was calculated using Hoyt's (1979) equation:

Mass $=0.000548 \times \mathrm{LB}^{2}$

where $\mathrm{L}$ is egg length in $\mathrm{mm}$ and $\mathrm{B}$ is egg breadth in $\mathrm{mm}$. Carapace length for the gravid female turtle that produced MOR 710 is estimated using the positive correlation between egg mass and adult carapace length (Elgar and Heaphy, 1989) and the regression line:

$\mathrm{y}=0.0568 \mathrm{x}+1.5811$

The latter was derived from 63 species (Elgar and Heaphy, 1989: Appendix), where $\mathrm{y}$ is the egg mass and $\mathrm{x}$ is carapace length $\left(r^{2}=0.666\right)$. Note that the regression equation provided in Elgar and Heaphy (1989: Fig. 1) contains a typographical error, which results in unrealistically small carapace lengths.

\section{Geology}

The Campanian (Upper Cretaceous) Judith River and Two Medicine formations in north-central Montana consist of eastward thinning, non-marine clastic deposits that record regressiveprogradational phases of shoreline migration of the Western Interior Cretaceous Seaway (Fig. 1A, B) (Lorenz, 1981; Rogers, 1998). The temporally and lithostratigraphically correlative formations are now separated by the Sweetgrass arch, a north-south-trending anticline (Fig. 1A, B). The Judith River Formation in eastern Montana includes deposits of a broad lowland coastal alluvial plain (Rogers, 1998). Marine rocks of the Claggett and Bearpaw formations underlie and overlie the formation, respectively (Rogers, 1998). Eberth et al. (1992) and Goodwin and Deino (1989) dated rocks of the Judith River Formation in central Montana as 74.5 and 78.0 Ma, respectively, which corresponds to the middle to late Campanian (Fig. 1B).

MOR 710 comes from a sandy siltstone in a fining-upward stratigraphic sequence representing overbank deposits at the Egg White Site (MOR locality JR-122L) in Hill County, near Havre, Montana (Clouse, 2001; Fig. 1). This specimen occurred approximately $4 \mathrm{~m}$ laterally from a clutch of lambeosaurine eggs preserved beneath a bentonite layer within the so-called upper nesting horizon of the lower nesting ground (Clouse, 2001). According to Clouse (2001), this nesting ground lies in the upper half of the Judith River Formation, deposited during the latter half of the Bearpaw Seaway transgression. Invertebrate fossils within the nesting horizon consist of freshwater and brackish species, including large unionid bivalves, as well as unidentified small bivalves and gastropods (Clouse, 2001). Vertebrate fossils include shed theropod and ornithopod teeth and fragmentary turtle shells referable to Basilemys sp., Adocus sp., Aspideretoides sp., and an undescribed large-bodied terrestrial form.

\section{Systematic paleontology}

Oofamily Testudoolithidae Hirsch, 1996 sensu Jackson et al., 2008

Oogenus Testudoolithus Hirsch, 1996 sensu Jackson et al., 2008

Oospecies Testudoolithus zelenitskyae oosp. nov.

Figs. 2-3

Holotype. MOR 710, the weathered remains of a clutch composed of at least 16 turtle eggs.

Etymology. After Darla Zelenitsky in recognition of her initial description of Adocus eggs from Alberta, Canada and continuing contribution to oological research.

Type locality and age. MOR locality JR-122L, Egg White Site, northcentral Montana, U.S.A, Judith River Formation, Upper Cretaceous (Campanian).

Diagnosis. Testudoolithus zelenitskyae oosp. nov. differs from all other oospecies in the following unique combination of characters: spherical turtle eggs 34-39 $\mathrm{mm}$ in diameter; 660-760 $\mu \mathrm{m}$ thick eggshell; shell unit height-to-width ratio of 3.15:1-5.5:1 and domed shell units.

Distribution. Judith River Formation, Montana, U.S.A. (Jackson and Schmitt, 2008, MOR 710), Oldman and Dinosaur Park formations, Alberta, Canada (Zelenitsky et al., 2008, TMP 1999.63.2 and TMP 2008.27.1, respectively), and Kaiparowits Formation, Utah, U.S.A. (Knell et al., 2011, NHMU 16868 [LBA-06-7]). All these formations are Campanian (Late Cretaceous) in age.

Description

Eggs. Eleven beige eggs (Fig. 2) measuring 34-39 $\mathrm{mm}$ in diameter occurred on a weathered surface eroded into a concretionary layer (Fig. 1C). The lithostatically compressed eggs are filled by sandy 

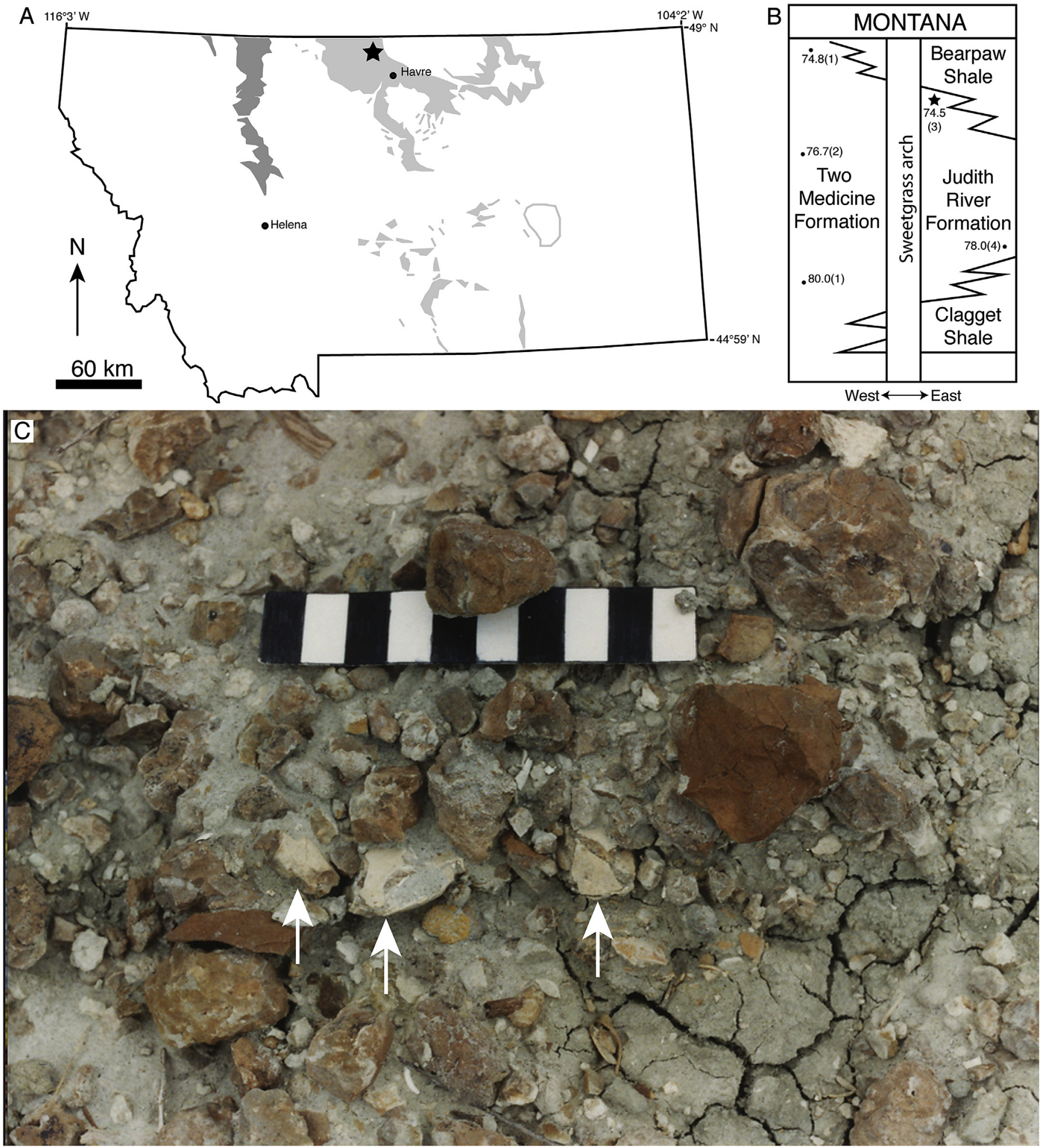

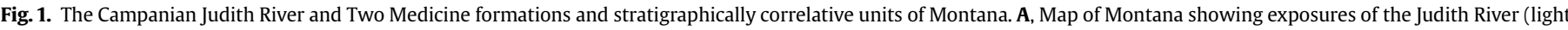

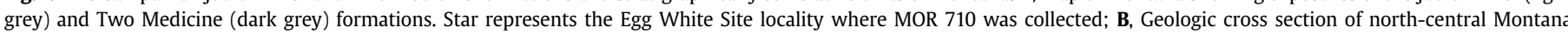

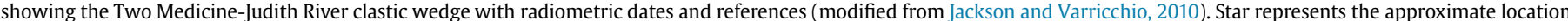

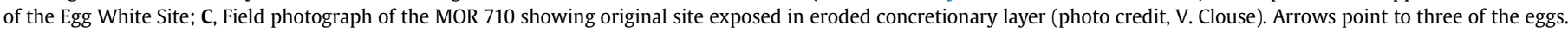
Scale bar equals $10 \mathrm{~cm}$. References: 1, Rogers et al. (1993); 2, Varricchio et al. (2010); 3, Eberth et al. (1992); 4, Goodwin and Deino (1989).

siltstone. These occurred in close association with one wellpreserved egg of the same color and four highly crushed, orange eggs, which were found in situ within a sandy siltstone matrix. The similarity of preservation and in-filling sediment suggest all eggs came from the same horizon and originally represented a clutch. In addition, all eggs exhibit relatively intact eggshell on both sides and thus appear to be unhatched. We estimate egg mass as $21.5-32.5 \mathrm{~g}$. The weathered condition of the material, however, prevents 

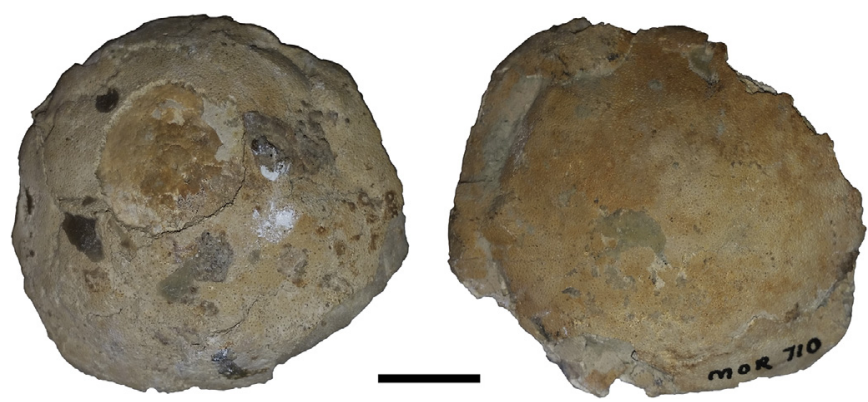

Fig. 2. MOR 710A and C, two lithologically compressed eggs with normal eggshell structure. Scale bar equals $1 \mathrm{~cm}$.

determination of the original number of eggs, their relative position to one another, and number of egg layers that once comprised the clutch.

Single-layered eggshell. The 660-760 $\mu \mathrm{m}$ thick eggshell is composed of a single layer of shell units; the latter average $135-240 \mu \mathrm{m}$ wide, with a height-to-width ratio of 3.15:1-5.5:1 (Fig. 3A, B). Shell units consist of tightly interlocking acicular aragonite crystals that radiate from nucleation sites at the inner shell surface (Fig. 3C). These crystals feather out at their terminal ends and the shell units exhibit domed ornamentation on the external surface. Wellpreserved craters, likely resulting from osteogenesis, occur at the base of some but not all shell units and measure $60 \mu \mathrm{m}$ in diameter (Fig. 3B). A straight tube-like pore that measures $50 \mu \mathrm{m}$ in diameter occurs between shell units and extends from the inner to the outer eggshell surfaces (Fig. 3A). Under cross-polarized light, the eggshell displays sweeping extinction. Remnants of 46-107 $\mu$ m-thick shell membrane are preserved below the inner shell surface and consist of two layers, which also characterize extant turtle eggs (Fig. 3B; Hirsch, 1983).

Multilayered eggshell. MOR 710B includes two eggshell layers. Preservation within MOR 710B is highly variable. Some specimens display substantial diagenetic alteration, primarily dissolution of aragonite and reprecipitation of calcite (Fig. 3D). The inner and outer eggshells measure 500-540 $\mu \mathrm{m}$ and 340-380 $\mu \mathrm{m}$, respectively, with a total thickness of $835-860 \mu \mathrm{m}$ (Fig. 3E, F). The inner surface of the lower eggshell has a shattered appearance, with splinter-like fragments of eggshell randomly oriented within the secondary mineral matrix. The inner eggshell layer is typically thinner than the single layered eggshell described above, likely due to this alteration. Although sometimes slightly separated from the inner eggshell, the overlying eggshell conforms closely to the external surface of the underlying shell units. Two eggshell fragments from different areas of the egg show no evidence of nucleation sites between the inner and outer eggshell layers under SEM (Fig. 3E and unpublished image). With the exception of one or possibly two nuclei, radial thin section from different fragments also show an absence of nuclei (Fig. 3F). Shell units in the outer eggshell layer have a height-to-width ratio of $1.65: 1$, and their external surfaces are typically flatter and lack the domed shape of the underlying ones. No pores were observed in the outer eggshell, whereas this layer truncates a pore of the underlying eggshell in at least one area of the shell (Fig. 3E).

Cathodoluminescence imaging of MOR 710B reveals dull blue luminescence throughout the specimen except for small areas of non-luminescence and/or bright orange luminescence that occur primarily between shell units at the inner shell surface, in pores between shell units and within dissolution cavities (Fig. 3D).

Embryonic remains. At least five eggs contain embryonic remains, including the multilayered specimen (MOR 710B) described above.
Although the state of embryonic preservation in MOR 710D prohibits a detailed description, we provide a brief anatomic and histologic assessment based on the available information from this egg.

Partial preparation of MOR 710D reveals well ossified and partially articulated embryonic skeletal elements that include the skull, lower jaw, fore and hindlimbs, as well as numerous unidentifiable bones (Fig. 4A, B). The skull and lower jaw are preserved in ventral view. Although, the premaxillae and maxillae are articulated, the remaining exposed cranial elements are disarticulated and unidentifiable. The triturating surfaces of the upper and lower jaws, as well as the palatal bones are not exposed. The lower jaw includes both dentaries, which exhibit a weakly sutured symphysis. The left forelimb preserves the manus and a possible radius, whereas the hindlimb elements include the right tibia, right fibula, as well as both right and left ungual phalanges. Numerous other unidentifiable postcranial elements are exposed on the partially prepped surface of the egg.

A histological thin section of a costal element (MOR 710:EB 3) shows that the embryonic bone consists of primary woven bone with numerous osteocyte lacunae and bony trabeculae that radiate from the medullary cavity and surround large vascular canals (Fig. 4C, D). There is no evidence of compact bone or bone remodeling. Bone growth dominates in the anteroposterior direction.

\section{Discussion}

The needle-like aragonite crystals allow definitive assignment of MOR 710 to Testudines (Hirsch, 1983). The generally well-preserved aragonite structure shows some dissolution and calcite replacement, with small areas of bright orange luminescence and areas of non-luminescent. Bright orange luminescence is due to $\mathrm{Mn}^{2+}$ incorporation into the calcite crystal (Marshall, 1988), which is generally linked to elevated $\mathrm{Mn}^{2+}$ concentrations (Wendler et al., 2012). Areas of non-luminescence may result from increased $\mathrm{Fe}^{2+}$, a main quencher element of $\mathrm{CL}$ in carbonates (Barbin, 2000; Boggs and Krinsley, 2006; Götte and Richter, 2009), or possibly because $\mathrm{Mn}^{2+}$ levels are below the detection limits (Barbin, 2000; Wendler et al., 2012). Some non-luminescent areas in the eggshell may represent open space in fractures that are unfilled by calcite.

In contrast to these small bright orange and non-luminescent areas, MOR 710B primarily exhibits a dull blue color, similar to CL imaging of extant and recent fossil turtle eggshell (Lawver and Jackson, in press; Lawver, unpublished data). Blue luminescence is thought to occur in the absence of activator elements (Wendler et al., 2012) and has been detected in the aragonite shells of Nautilus (Cephalopoda) that are only minimally affected by diagenetic overprint (Barbin et al., 1995). Blue luminescence in MOR 710B also suggests minimal diagenetic recrystallization of the aragonite eggshell.

\subsection{Parataxonomy}

Hirsch's (1996) parataxonomic classification for fossil turtle eggs and eggshells includes two oofamilies, Testudoflexoolithidae and Testudoolithidae. Flexible eggs with loosely abutting shell units comprise the former, whereas the latter includes rigid eggs with tightly packed shell units. The rigid structure of the eggshell excludes MOR 710 from Testudoflexoolithidae (Table 1).

Among oospecies assigned to Testudoolithidae, MOR 710 differs from Chelonoolithus braemi Kohring, 1998 and Haininchelys curiosa Schleich et al., 1988 in its thicker eggshell and a shell unit height-to- 
A

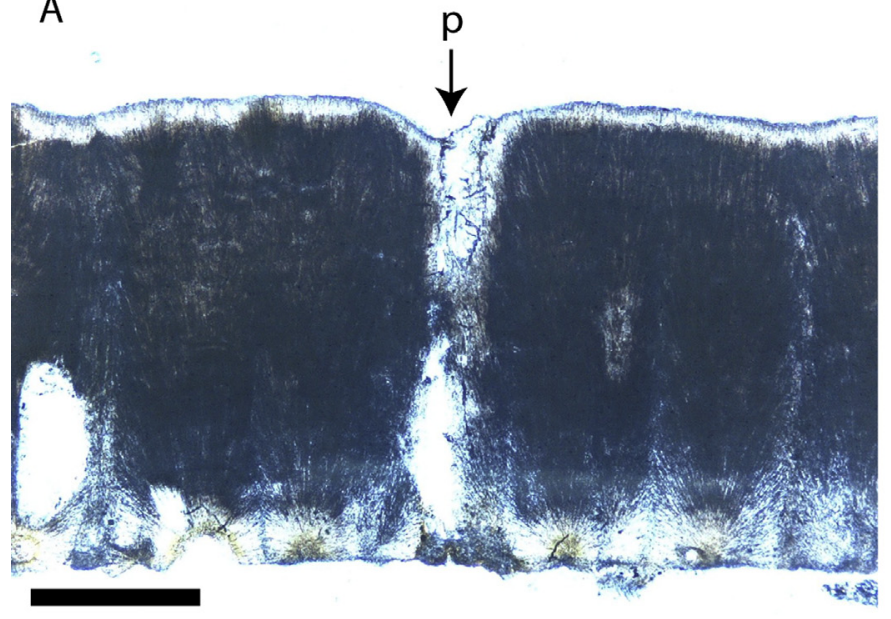

B

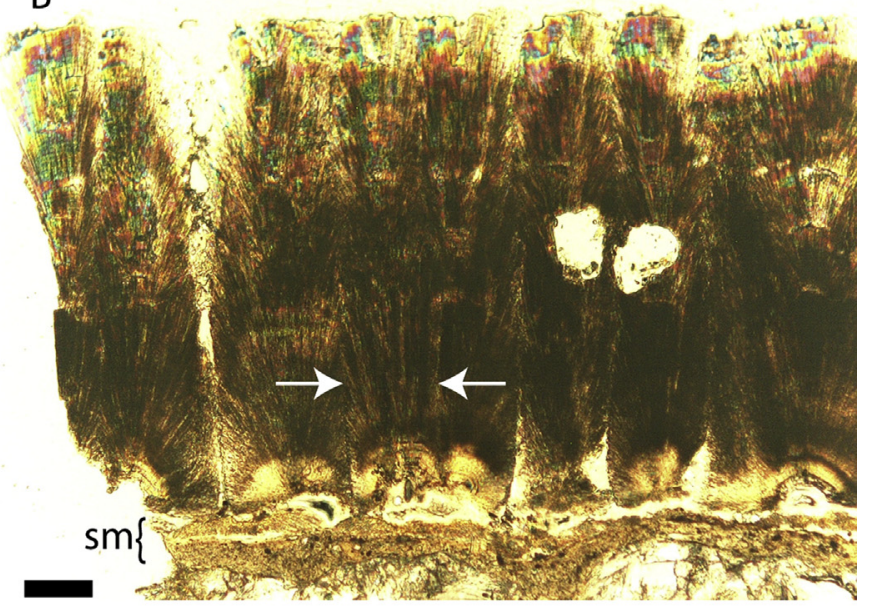

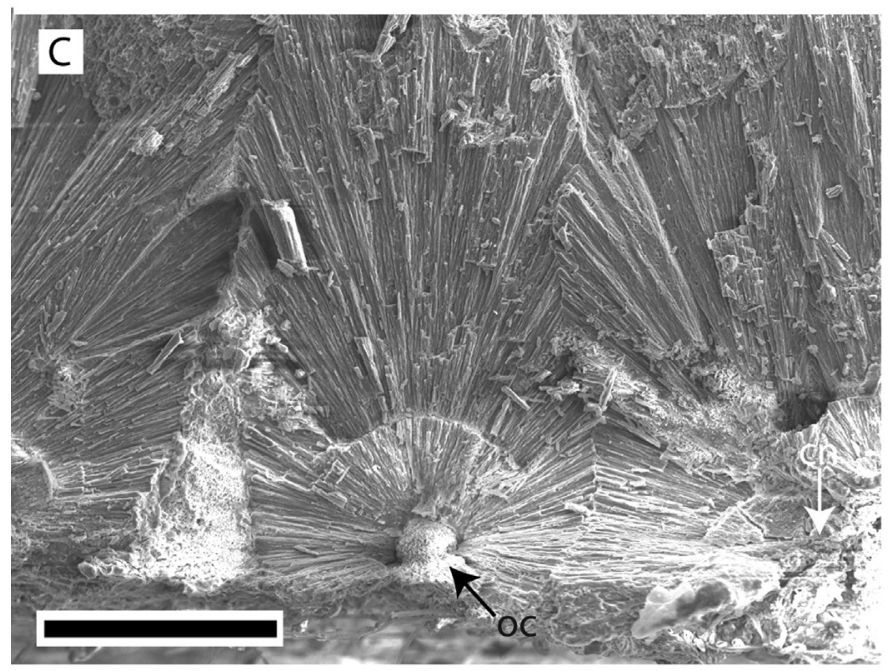
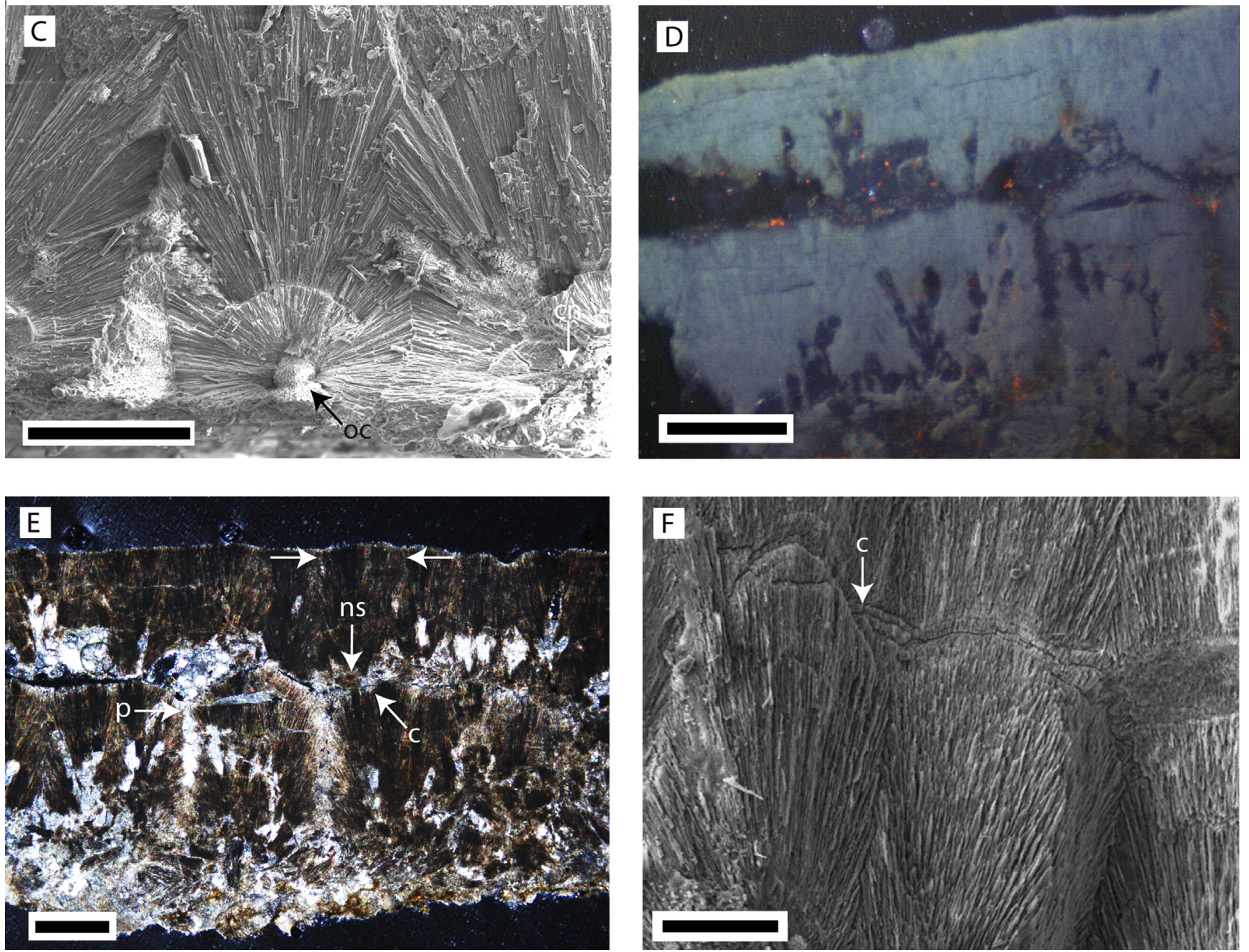

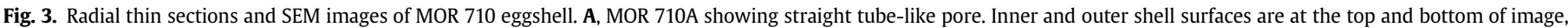

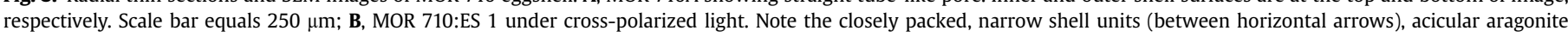

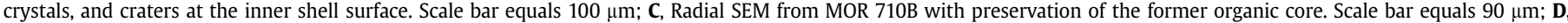

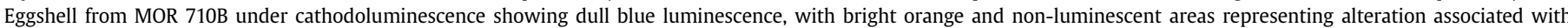

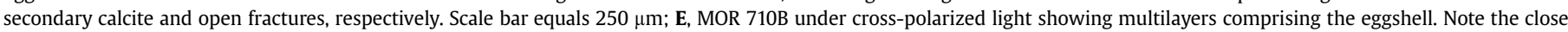

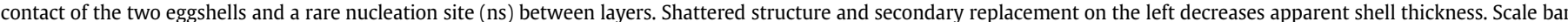

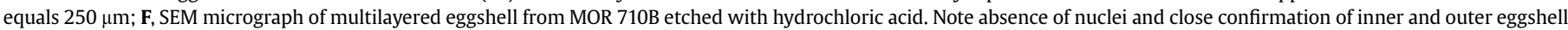

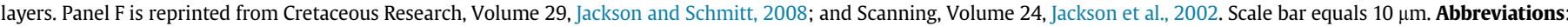

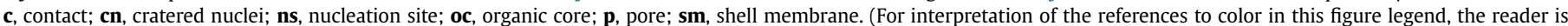
referred to the web version of this article.) 

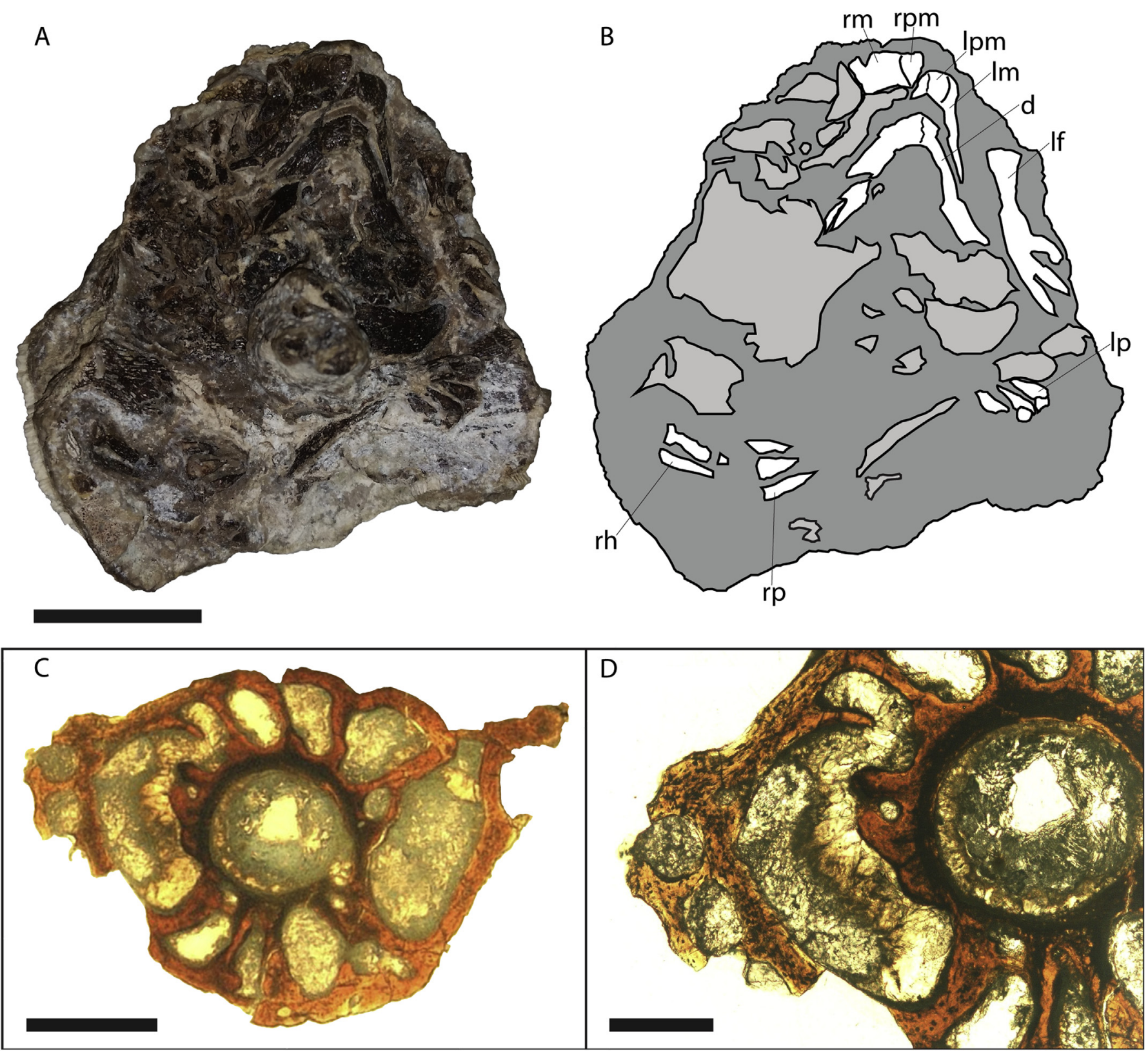

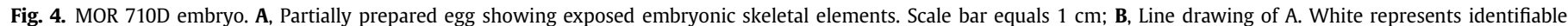

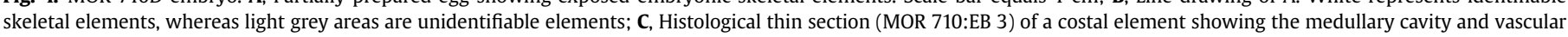

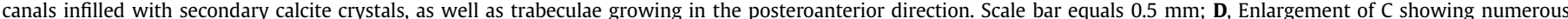

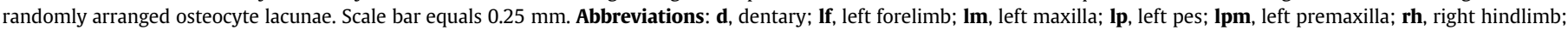
$\mathbf{r m}$, right maxilla; rp, right pes; rpm, right premaxilla.

width ratio of 3.15:1-5.5:1. MOR 710 can be distinguished from Emydoolithus laiyangensis Wang et al., 2013 in overall eggs shape, thicker eggshell, and a greater height-to-width ratio. Thicker eggshell also distinguishes MOR 710 from Testudoolithus hirschi Kohring, 1999, and T. rigidus Hirsch, 1996. MOR 710 is similar to Testudoolithus jiangi Jackson et al., 2008 (Fang et al., 2003) and the eggs fall within the ranges of egg size and eggshell thickness of this ootaxon; however, MOR 710 has a greater shell unit height-towidth ratio.

\subsection{Taxonomy}

MOR 710 could potentially represent the eggs of one of several turtle taxa known from the Judith River Formation: Axestemys splendida, Aspideretoides sp., Plastomenus sp., Basilemys sp., Neurankylus eximius, Plesiobaena antiqua, and Adocus sp. (Sahni, 1972; Vitek, 2012; Joyce and Bourque, 2016). The trionychids Axestemys splendida and Plastomenus sp. seem unlikely candidates because extant trionychid eggs differ from MOR 710 in their thinner eggshell $(0.1-0.2 \mathrm{~mm})$, smaller height-to-width ratio, and lack of domed external surfaces (Fig. 5). A gravid Basilemys variolosa from the stratigraphically correlative Dinosaur Park Formation in Alberta, Canada could potentially provide identification; however, Braman and Brinkman (2009) failed to describe the eggshell microstructure, thereby precluding comparison to MOR 710. The eggs of $N$. eximius and $P$. antiqua are currently unknown, although $N$. eximius may have been large enough to produce a similar sized clutch as MOR 710. Taxa from the Judith River Group of Alberta 
include Judithemys sukhanovi and Boremys pulchra; however, eggs of these taxa are also currently unknown. Additionally, J. sukhanovi may have been capable of producing a clutch as large as MOR 710 .

The eggshell microstructure of most eggs within MOR 710 is most similar to eggs preserved within a gravid Adocus sp. and a fossil egg clutch from Alberta, Canada (Zelenitsky et al., 2008). Similarities include thick eggshell, with shell units taller than wide, and a domed external surface (see Table 2). In her unpublished master's thesis Zelenitsky (1995) named these Adocus sp. eggs Testudoolithus magnirigidus; however, this name does not meet the criteria of the International Committee on Zoological Nomenclature (Article 8.1.3) that requires simultaneously obtainable copies and wide distribution. Consequently, this oospecies is a nomen nudum (Lawver and Jackson, 2014) and we name the new ootaxon Testudoolithus zelenitskyae. A significant amount of homoplasy occurs in extant turtle eggshells (Winkler, 2006; Lawver, 2012) and, therefore, Testudoolithus zelenitskyae oosp. nov. could potentially belong to another, as yet undescribed extinct taxa of close phylogenetic affinity to Adocus. Therefore, we assign the eggs to parataxonomy for better comparison with other egg types as well as allowing for the possibility of homoplastic morphology shared among multiple taxa.

\subsection{Embryonic remains}

The embryonic remains provide only limited information. Nevertheless, some morphological and histological comparisons are possible with comparison to the extant trionychid Apalone spinifera. For example, preservation of anteroposteriorly projecting bony trabeculae of the costal elements (Fig. 4C, D) coincides with the initial expansion of this element in order to form the costal plates of the carapace. In A. spinifera this expansion begins no later than Stage 23 (Sheil, 2003), thus suggesting that the fossil embryos obtained 23 of 25 embryonic developmental stages prior to their demise. Additionally, embryos of the more distantly related taxa, Chelydra serpentina, Macrochelys temminckii, and Phrynops hilarii also possess well-developed phalanges at stage 23 (Sheil, 2005; Sheil and Greenbaum, 2005; Bona and Alcalde, 2009). Finally, the well-ossified embryonic bones that characterize all eggs within

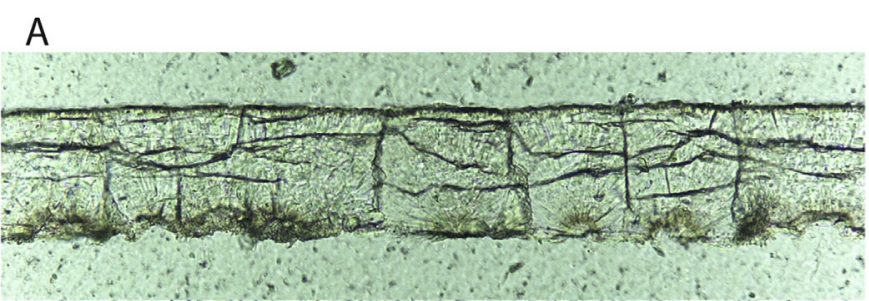

B

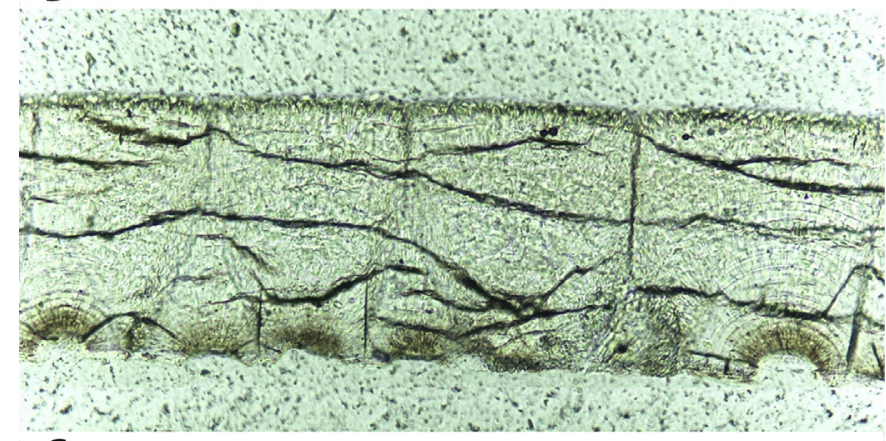

C

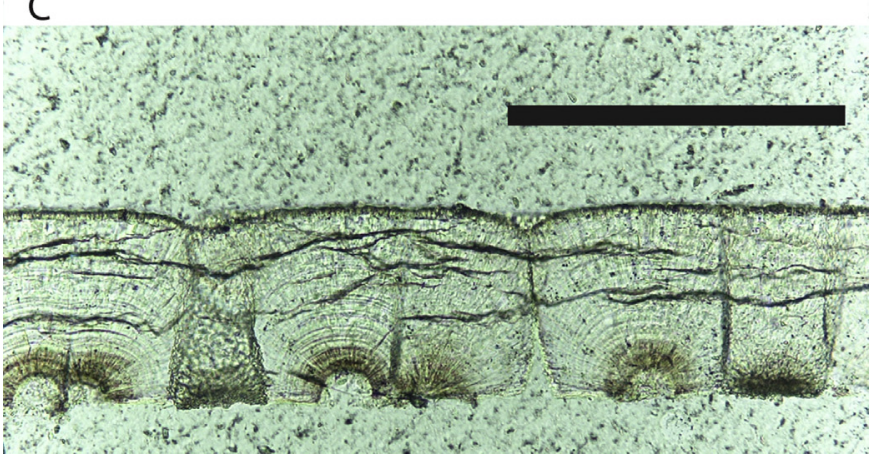

Fig. 5. Radial thin sections of extant trionychid eggshell. A, Apalone mutica eggshell (ES 203); B, Apalone ferox eggshell (ES 204); C, Apalone spinifera eggshell (ES 205). Scale bar equals $250 \mu \mathrm{m}$.

Table 1

List of turtle ootaxa and their distinguishing characteristics.

\begin{tabular}{|c|c|c|c|c|c|c|}
\hline Ootaxon & Holotype: Material & $\begin{array}{l}\text { Geographic and temporal } \\
\text { distribution }\end{array}$ & Egg shape & $\begin{array}{l}\text { Length } \times \\
\text { width }(\mathrm{mm})\end{array}$ & $\begin{array}{l}\text { Eggshell thickness } \\
(\mathrm{mm})\end{array}$ & $\begin{array}{l}\text { Shell unit } \\
\text { (height:width) }\end{array}$ \\
\hline Testudoflexoolithus agassizi ${ }^{1}$ & $\begin{array}{l}\text { MCZ 2810/HEC 49: Eggshell } \\
\text { fragments }\end{array}$ & Florida, USA; Pleistocene & - & - & $0.06-0.1$ & $1: 1$ or $2: 3$ \\
\hline Testudoflexoolithus bathonicae $e^{1,2}$ & $\begin{array}{l}\mathrm{MB}(\mathrm{NH}) 37983 / \mathrm{HEC} 186 \text { : } \\
\text { An egg imbedded in matrix }\end{array}$ & England; Bathonian, Middle Jurassic & Ellipsoidal & $48 \times 26$ & $0.2-0.25$ & $1: 1$ \\
\hline Chelonoolithus braemi ${ }^{3}$ & $\begin{array}{l}\text { Guimarota 98-2: Eggshell } \\
\text { fragments }\end{array}$ & $\begin{array}{l}\text { Portugal; Kimmeridgian, } \\
\text { Upper Jurassic }\end{array}$ & - & - & 0.2 & $1: 1$ \\
\hline Emydoolithus laiyangensis ${ }^{4}$ & $\begin{array}{l}\text { IVPP V18544: A nearly } \\
\text { complete egg }\end{array}$ & $\begin{array}{l}\text { Shandong Province, China; } \\
\text { Upper Cretaceous }\end{array}$ & Elongate & $91 \times 22$ & $0.4-0.5$ & $2: 1$ to $5: 1$ \\
\hline Haininchelys curiosa ${ }^{5}$ & -: Eggshell fragments & Belgium; Upper Paleocene & - & - & $0.25-0.3$ & $1.2: 1$ to $2.3: 1$ \\
\hline Testudoolithus hirschi ${ }^{6}$ & -: Eggshell fragments & $\begin{array}{l}\text { Portugal; Kimmeridgian, } \\
\text { Upper Jurassic }\end{array}$ & - & - & 0.15 & $3: 1$ \\
\hline Testudoolithus jiangi ${ }^{7,8}$ & $\begin{array}{l}\text { ZMNH M8713: A clutch } \\
\text { of } 23 \text { eggs }\end{array}$ & $\begin{array}{l}\text { Zhejiang Province, China; Albian, } \\
\text { Early Cretaceous }\end{array}$ & Spherical & $35-52$ & $0.7-1.0$ & $2.5: 1$ to $3: 1$ \\
\hline Testudoolithus rigidus $^{1}$ & $\begin{array}{l}\text { UCM 55806/HEC } 425: \\
\text { Half of an egg }\end{array}$ & $\begin{array}{l}\text { U.S.A., Europe, Africa; Lower } \\
\text { Cretaceous - Pliocene }\end{array}$ & Spheroidal & $42 \times 47$ & $0.22-0.24$ & $2: 1$ \\
\hline Meiolania platyceps eggs ${ }^{9}$ & $\begin{array}{l}\text { AM F82183: A clutch } \\
\text { of at least } 10 \text { eggs }\end{array}$ & $\begin{array}{l}\text { Lord Howe Island, Australia; } \\
\text { Pleistocene }\end{array}$ & Spherical & 53.9 & 0.8 & $1.2: 1$ \\
\hline Testudoolithus zelenitskyae & $\begin{array}{l}\text { MOR 710: A clutch } \\
\text { of at least } 16 \text { eggs }\end{array}$ & $\begin{array}{l}\text { U.S.A. and Canada; Campanian, } \\
\text { Upper Cretaceous }\end{array}$ & Spherical & $34-39$ & $660-760$ & $3.15: 1$ to $5.5: 1$ \\
\hline
\end{tabular}

Modified from Lawver and Jackson (2014).

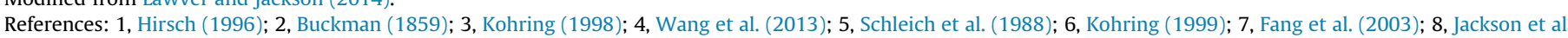
(2008); 9, Lawver and Jackson (in press). 
MOR 710 also suggest that termination of embryonic development occurred close to hatching.

\subsection{Multilayered eggshell}

The multiple eggshell layers of MOR 710B closely resembles a pathological condition reported in extant turtle eggs, whereby one or more additional eggshell layer is deposited over the original egg (Erben et al., 1979; Ewert et al., 1984; Jackson and Varricchio, 2003). However, the presence of an embryo in an advanced stage of development in a pathological egg is surprising. Here, we discuss alternative explanations that may account for this unusual occurrence.

First, the additional layer is biological in origin. This multilayered condition is relatively common in extant turtles, currently described for at least nine taxa (Jackson et al., 2004 and reference therein). The additional shell layers result from prolonged retention of one or more eggs in the uterus due to physiological or environmental stresses (Erben et al., 1979; Ewert et al., 1984). The abnormal layer(s) often block the pore canals of the underlying eggshell, and termination of embryonic development often results from asphyxiation. However, in at least one case an extant turtle embryo from a multilayered egg survived to hatching and died shortly thereafter (personal communication, M. Ewert, May, 2001, Bloomington, IN). If the outer eggshell in MOR 710B resulted from egg retention, the pores in the inner and outer eggshells may have aligned and extended through both layers in some areas of the egg, permitting limited but potentially adequate embryonic gas exchange during embryonic development. For example, Ewert et al. (1984) described a pore in an abnormal Rhinoclemmys areolata eggshell that extended straight through three superimposed layers.

A phenomenon known as egg capping offers an alternative explanation for the second layer in MOR 710B. Although rare in avian species $(\leq 1 \%)$, a portion of a hatched egg occasionally "caps" an adjacent, unhatched egg (Derrickson and Warkentin, 1991; Verbeek, 1996). If this shell fragment is not removed by the adult, the embryo may suffocate. Derrickson and Warkentin (1991) speculated that egg capping might occur more often in clutches with greater hatching asynchrony and egg size variability. Hauber (2003), however, felt that this was not feasible to address because of the lack of published comparative data. Further, Hauber (2003) reports that no eggs in his study $(0 \%)$ were covered by eggshell from conspecific eggs, whereas egg capping occurred in 33\% of eggs from parasitized nests. The parasitic eggs were larger and hatched earlier than the host eggs, thereby increasing the potential for egg capping.

We interpret the multiple layers in MOR 710B as an abnormality for the following reasons. 1) Egg capping is unreported in extant turtles and other reptile eggs, likely because of their incubation in a substrate or vegetation mound, rather than in open nests characteristic of birds. 2) The inner surface of the outer layer of MOR 710B follows the contour of the underlying shell units (Fig. 3E, F) and its outer surface lacks the domed shape of normal eggshell. 3 ) None of the eggs in the turtle clutch appear hatched; to the contrary, the eggs contain well-formed embryos that suggest an advanced stage and synchronous embryonic development; missing eggshell most likely resulted from recent weathering. 4) Most importantly, the base of the shell units in the outer eggshell layer lack nucleation sites (Fig. 3E, F). We identified only one or possibly two nuclei in samples viewed in thin section (Fig 3E) and none under SEM. If the second layer in MOR 710B represented a fragment from a previously hatched egg one would expect nucleation sites at the base of each shell unit. These are clearly absent in most areas of the eggshell (Fig. 3E).

As a final note, in extant multilayered eggs, shell membrane may or may not occur between the inner and outer eggshell layers (Ewert et al., 1984). This variation also occurs in Mesozoic multilayered eggshells (Jackson et al., 2008). If present in MOR 710B, decay of the membrane may have provided a conduit for ground water, thus contributing to more extensive recrystallization and precipitation of calcite between the layers in some areas of the egg (Fig. 3E).

\subsection{Ecological inferences}

The size, shape, and estimated mass (21.5-32.5 g) of eggs preserved in MOR 710 allow anatomical and ecological interpretations. Extant turtles that lay spherical eggs are generally of large body size (Elgar and Heaphy, 1989) and have large clutches because this shape permits simultaneously shelling of more eggs in the uterus prior to oviposition (Ewert, 1979; Iverson and Ewert, 1991). We estimate carapace length for the gravid female turtle that produced MOR 710 as $35.0-54.4 \mathrm{~cm}$ using the positive correlation between egg mass and adult carapace length (Elgar and Heaphy, 1989). However, it is worth noting that rigid-shelled turtle eggs have a density of 1.126 , whereas birds have a density of 1.03-1.09 (Iverson and Ewert, 1991). This indicates that the egg mass and carapace lengths calculated here represent minimum estimates. These egg characteristics (i.e., size, shape, mass) suggest that MOR 710 was produced by a large bodied taxon. This inference is further supported by carapace length estimates of the gravid Adocus sp. specimens from Alberta and Utah (Zelenitsky et al., 2008; Knell et al., 2011). The $40.5 \mathrm{~cm}$ long Alberta adult preserves at least five eggs, with a diameter of approximately 35-40 mm (Zelenitsky et al., 2008). Likewise the 50-55 cm-long gravid adult from Utah preserves at least two eggs with diameter of $35 \mathrm{~mm}$. Both gravid specimens (e.g., Zelenitsky et al., 2008; Knell et al., 2011) are estimated to have originally contained more eggs than observed.

Table 2

Egg/eggshell characteristics of Testudoolithus zelenitskyae oosp. nov. and Adocus sp. specimens discussed in the text.

\begin{tabular}{|c|c|c|c|c|c|c|}
\hline Specimen & Material & Formation & Egg shape & Length $\times$ width $(\mathrm{mm})$ & Eggshell thickness (mm) & $\begin{array}{l}\text { Shell unit } \\
\text { (height:width) }\end{array}$ \\
\hline MOR 710 & $\begin{array}{l}\text { Weather clutch of at } \\
\text { least } 16 \text { eggs }\end{array}$ & Judith River Formation & Spherical & $34-39$ & $0.66-0.76$ & $3.15: 1-5.5: 1$ \\
\hline NHMU 16868 (LBA-06-7) ${ }^{1}$ & $\begin{array}{l}\text { Gravid Adocus sp. preserving } \\
\text { at least two eggs }\end{array}$ & Kaiparowits Formation & Spherical & 35 & $0.25-0.28$ & $2.5: 1$ \\
\hline TMP $1999.63 .2^{2}$ & $\begin{array}{l}\text { Gravid Adocus sp. preserving } \\
\text { at least five eggs }\end{array}$ & Oldman Formation & Spherical & $35-40$ & $0.73-0.81$ & $2.5: 1$ \\
\hline TMP 2008.27.12 & Clutch of at least 26 eggs & Dinosaur Park Formation & Spherical & $\begin{array}{l}40 \times 42 \\
40 \times 43\end{array}$ & $0.5-0.65$ & $3.5: 1$ \\
\hline
\end{tabular}

Note: All specimens are Late Cretaceous, Campanian in age.

References: 1, Knell et al. (2011); 2, Zelenitsky et al. (2008). 


\section{Conclusions}

MOR 710 comes from the Campanian (Upper Cretaceous) Judith River Formation of north-central Montana and consists of a weathered accumulation of eggs interpreted as remnants of a clutch originally composed of at least 16 spherical turtle eggs, at least one of which displays an additional, abnormal eggshell layer. Normal eggs exhibit a $660-760 \mu \mathrm{m}$ thick eggshell comprised of a single layer of tightly interlocking aragonite shell units with a height-to-width ratio of 3.15:1-5.5:1. In contrast, the abnormal eggshell includes 500-540 $\mu \mathrm{m}$ and 340-380 $\mu \mathrm{m}$-thick inner and pathological shell layers, respectively. The pathological layer likely represents a retained egg from the same or different nesting attempt due to physiological or environmental stress experienced by the female turtle. When compared to the extant trionychid, Apalone spinifera, the embryonic bones in at least five eggs (including the multilayered specimen) demonstrate a late stage of development. This indicates that these embryos were close to hatching when death occurred. The similarity of the eggshell microstructure between the Judith River eggs and that of Adocus sp. (Zelenitsky et al., 2008; Knell et al., 2011) suggests that this taxon might have produced MOR 710. Further descriptions of taxonomically identifiable fossil turtle eggs, such as those from the Canadian gravid Basilemys variolosa specimen, will help support or refute this identification.

\section{Funding}

This research did not receive any specific grant from funding agencies in the public, commercial, or not-for-profit sectors.

\section{Acknowledgments}

We thank John Horner for access to the specimens and use of the Gabriel Laboratory for Cellular and Molecular Paleontology, Bozeman, MT. Vicky Clouse provided the locality photo used in Fig. 1C. Ellen Lamm assisted with histology. Torsten Scheyer and David Varricchio provided informative discussions on embryonic turtle histology. The Department of Earth Sciences and the Image and Chemical Analysis Laboratory, Montana State University (Bozeman, MT) provided laboratory equipment. The Chelonian Research Foundation Linnaeus Fund, the Paleontological Society Steven Jay Gould Award, and a Grant-In-Aid of Research from Sigma Xi, The Scientific Research Society (D. Lawver) funded this research. Permission was granted by Elsevier and John Wiley and Sons for the reproduction of a figure originally published in the journals Scanning and Cretaceous Research, respectively. Finally, we thank an anonymous reviewer and T. Szczygielski for comments that greatly improved the manuscript.

\section{References}

Anderson, C., 1925. Notes on the extinct chelonian Meiolania, with a record of a new occurrence. Records of the Australian Museum 14, 223-242.

Barbin, V., 2000. Cathodoluminescence of carbonate shells: biochemical vs diagenetic process. In: Pagel, M., Barbin, V., Blanc, P., Ohnenstetter, D. (Eds.), Cathodoluminescence in Geosciences. Springer, New York, pp. 303-328.

Barbin, V., Brand, U., Hewitt, R.A., Ramseyer, K., 1995. Similarity in Cephalopod shell biogeochemistry since Carboniferous: evidence from cathodoluminescence. Geobios 28, 701-710.

Boggs Jr., S., Krinsley, D., 2006. Applications of Cathodoluminescence Imaging to the Study of Sedimentary Rocks. Cambridge University Press, New York.

Bona, P., Alcalde, L., 2009. Chondrocranium and skeletal development of Phrynops hilarii (Pleurodira: Chelidae). Acta Zoologica 90, 301-325.

Braman, D.R., Brinkman, D.B. (Eds.), 2009. Guidebook to Geology and Palaeontology of Dinosaur Provincial Park, Alberta. Special Publication of the Royal Tyrrell Museum, Drumheller, $82 \mathrm{pp}$.

Buckman, J., 1859. On some fossil reptilian eggs from the Great Oolite of Cirencester. Quarterly Journal of the Geological Society 16, 107-110.
Clouse, V.R., 2001. Stratigraphy and paleogeography of dinosaur nesting grounds, Judith River Formation (Upper Cretaceous) north-central Montana: dinosaur nesting on a tidally influenced coastal lowland plain. M.S. thesis. Montana State University - Northern, Havre, Montana, 120 pp.

Cohen, S., Cruickshank, A., Joysey, K., Manning, T., Upchurch, P., 1995. The Egg and Embryo Exhibition Guide. Rock Art Publishing, Leicester, U.K., 16 pp.

Derrickson, K.C., Warkentin, I.G., 1991. The role of egg-capping in the evolution of eggshell removal. The Condor 93, 757-759.

Eberth, D.A., Thomas, R.G., Deino, A., 1992. Preliminary K-Ar dates from bentonites in the Judith River and Bearpaw formations (Upper Cretaceous) of Dinosaur Provincial Park, southern Alberta, Canada. In: Mateer, N.G., Chen, P.J. (Eds.) Aspects of Nonmarine Cretaceous Geology. China Ocean Press, Beijing, China, pp. 296-304.

Elgar, M.A., Heaphy, L.J., 1989. Covariation between clutch size, egg weight and egg shape: comparative evidence for chelonians. Journal of Zoology 219, 137-152.

Erben, H.K., Hoefs, J., Wedepohl, K.H., 1979. Paleobiological and isotopic studies of eggshells from a declining dinosaur species. Paleobiology 5, 380-414.

Ewert, M.A., 1979. The embryo and its egg: development and natural history. In: Harless, M., Morlck, H. (Eds.), Turtles: Perspectives and Research. Wiley Interscience, New York, New York, pp. 333-413.

Ewert, M.A., Firth, S.J., Nelson, C.E., 1984. Normal and multiple eggshells in batagurine turtles and their implications for dinosaurs and other reptiles. Canadian Journal of Zoology 62, 1834-1841.

Fang, X., Lu, L., Jiang, Y., Yang, L., 2003. Cretaceous fossil eggs from the Tiantai basin of Zhejiang, with a discussion on the extinction of dinosaurs. Geological Bulletin of China 22, 512-520.

Fang, X., Yue, Z., Ling, H., 2009. Review of the past 15 years' research on fossil eggs in China. Acta Geoscientica Sinica 30, 523-542.

Gaffney, E.S., 1996. The postcranial morphology of Meiolania platyceps and a review of the Meiolaniidae. Bulletin of the American Museum of Natural History 229,1-165.

Goodwin, M.B., Deino, A.L., 1989. The first radiometric ages from the Judith River Formation (Upper Cretaceous), Hill County, Montana. Canadian Journal of Earth Sciences 26, 1384-1391.

Götte, T., Richter, D.K., 2009. Quantitative aspects of Mn-activated cathodoluminescence of natural and synthetic aragonite. Sedimentology 56, 483-492.

Hauber, M.E., 2003. Egg-capping is a cost paid by hosts of interspecific brood parasites. The Auk 120, 860-865.

Hemprich, A., 1932. Fossile Gelege der Sumpfschildkröte in diluvialen Sü wasserKalken bei Halberstadt. Das Aquarium 5, 78-80 (German).

Hirsch, K.F., 1983. Contemporary and fossil chelonian eggshells. Copeia 1983, 382-397.

Hirsch, K.F., 1996. Parataxonomic classification of fossil chelonian and gecko eggs. Journal of Vertebrate Paleontology 16, 752-762.

Hoyt, D.F., 1979. Practical methods of estimating volume and fresh weight of bird eggs. Auk 96, 73-77.

International Commission on Zoological Nomenclature (ICZN), 1999. International Code of Zoological Nomenclature. The International Trust for Zoological Nomenclature, London, 306 pp.

Iverson, J.B., Ewert, M.A., 1991. Physical characteristics of reptilian eggs and a comparison with avian eggs. In: Deeming, D.C., Ferguson, M.W.J. (Eds.), Egg Incubation: Its Effect on Embryonic Development in Birds and Reptiles. Cambridge University Press, New York, pp. 88-100.

Jackson, F.D., Schmitt, J.G., 2008. Recognition of vertebrate egg abnormalities in the Upper Cretaceous fossil record. Cretaceous Research 29, 27-39.

Jackson, F.D., Varricchio, D.J., 2003. Abnormal, multilayered eggshell in birds: implications for dinosaur reproductive anatomy. Journal of Vertebrate Paleontology 23, 699-702.

Jackson, F.D., Varricchio, D.J. 2010. Fossil eggs and eggshell from the lowermost Two Medicine Formation of western Montana, Sevenmile Hill locality. Journal of Vertebrate Paleontology 30, 1142-1156.

Jackson, F.D., Schweitzer, M.H., Schmitt, J.G., 2002. Dinosaur eggshell study using scanning electron microscopy. Scanning 24, 217-223.

Jackson, F.D., Garrido, A., Schmitt, J.G., Chiappe, L.M., Dingus, L., Loope, D.B., 2004. Abnormal, multilayered titanosaur (Dinosauria: Sauropoda) eggs from in situ clutches at the Auca Mahuevo locality, Neuquén Province, Argentina. Journal of Vertebrate Paleontology 24, 913-922.

Jackson, F.D., Jin, X., Varricchio, D.J., Azuma, Y., Jiang, Y., 2008. The first in situ turtle clutch from the Tiantai basin, Zhejiang Province, China. Journal of Vertebrate Paleontology 28, 319-325.

Joyce, W.G., Bourque, J.R., 2016. A review of the fossil record of turtles of the clade Pan-Kinosternoidea. Bulletin of the Peabody Museum of Natural History 57, 57-95.

Joyce, W.G., Zelenitsky, D.K., 2002. Turtle egg pseudomorphs from the Late Jurassic of Schamhaupten, Germany. Archaeopteryx 20, 57-62.

Knell, M.J., Jackson, F.D., Titus, A.L., Albright III, L.B., 2011. A gravid fossil turtle from the Upper Cretaceous (Campanian) Kaiparowits Formation, southern Utah. Historical Biology 23, 57-62.

Kohring, R., 1998. Neue Schlidkröten-Eischalen aus dem Oberjura der Grube Guimarota (Portugal). Berliner Geowissenshaftliche Abhandlungen 28, 113-117.

Kohring, R., 1999. Strukturen, Biostratinomie, systematische und phylogenetische Relevanz von Eischalen amnioter Wirbeltiere. Courier Forschungsinstitut Senckenberg 210, 1-640.

Lamm, E.T., 2013. Preparation and sectioning of specimens. In: Padian, K. Lamm, E.T. (Eds.), Bone Histology of Fossil Tetrapods: Advancing Methods, 
Analysis, and Interpretation. University of California Press, Berkeley, California, pp. 55-160.

Lawver, D.L., 2012. Fossil and modern turtle eggshell: testing the validity of eggshel characters in cladistics analyses. In: Program and Abstracts of the 72nd Annual Meeting of the Society of Vertebrate Paleontology. Journal of Vertebrate Paleontology 32 (Suppl. 2), 126.

Lawver, D.L., Jackson, F.D., 2014. A review of the fossil record of turtle reproduction: eggs, embryos, nests and copulating pairs. Bulletin of the Peabody Museum of Natural History 55, 215-236.

Lawver, D.L., Jackson, F.D., 2016. A fossil egg clutch from the stem turtle Meiolanid platyceps: implications for the evolution of turtle reproductive biology. Journal of Vertebrate Paleontology (in press).

Lorenz, J.C., 1981. Sedimentary and tectonic history of the Two Medicine Formation Late Cretaceous (Campanian), northwestern Montana. Ph. D. dissertation. Princeton University, Princeton, New Jersey, 215 pp.

Marshall, D.J., 1988. Cathodoluminescence of Geological Materials. Unwin Hyman, Boston, MA.

McGee, A.R., 2012. A fossilized turtle egg clutch with embryos from the Upper Cretaceous Oldman Formation, southeastern Alberta: description, taxonomic identity, and embryonic staging. M.S. thesis. University of Calgary, Calgary, Alberta, 127 pp.

Mikhailov, K.E., Sabath, K., Kurzanov, S., 1994. Eggs and nests from the Cretaceous of Mongolia. In: Carpenter, K., Hirsch, K.F., Horner, J.R. (Eds.), Dinosaur Eggs and Babies. Cambridge University Press, pp. 88-115.

Mueller-Töwe, I.J., Kjeldahl-Vallon, T.A., Milàn, J., Vallon, L.H., Theodorou, G., Lindgren, J., Roussiakis, S.J., Bromley, R.G., 2011. First chelonian eggs and carapace fragments from the Pliocene of Rhodes, Greece. Neues Jahrbuch für Geologie und Paläontologie, Abhandlungen 262, 309-322.

Rasband, W., 1997. ImageJ. National Institution of Health, Bethesda, Maryland.

Rogers, R.R., 1998. Sequence analysis of the Upper Cretaceous Two Medicine and Judith River formations, Montana: nonmarine response to the Claggett and Bearpaw marine cycles. Journal of Sedimentary Research 68, 615-631.

Rogers, R.R., Swisher, C.C., Horner, J.R., 1993. ${ }^{40} \mathrm{Ar} /{ }^{39} \mathrm{Ar}$ age and correlation of the non-marine Two Medicine Formation (Upper Cretaceous), northwestern Montana. Canadian Journal of Earth Sciences 30, 1066-1075.

Sahni, A., 1972. The vertebrate fauna of the Judith River Formation, Montana. Bulletin of the American Museum of Natural History 147, 321-412.
Schleich, H.H., Kästle, W., van Dyck, M.G., 1988. Paläogene Eischalenreste von Hainin (Belgien). Paläontologische Zeitschrift 62, 133-146.

Sheil, C.A., 2003. Osteology and skeletal development of Apalone spinifera (Reptilia: Testudines: Trionychidae). Journal of Morphology 256, 42-78.

Sheil, C.A., 2005. Skeletal development of Macrochelys temminckii (Reptilia: Testudines: Chelydridae). Journal of Morphology 263, 71-106.

Sheil, C.A., Greenbaum, E., 2005. Reconstruction of skeletal development of Chelydra serpentina (Reptilia: Testudines: Chelydridae): evidence for intraspecific variation. Journal of Zoology 265, 235-267.

Varricchio, D.J., Koeberl, C., Raven, R.F., Wolbach, W., Elsik, W.C., Miggins, D.P., 2010. Tracing the Manson impact event across the Western Interior Cretaceous Seaway. In: Reimod, W.U., Gibson, R.L. (Eds.), Proceedings of the Conference on Large Meteorite Impact and Planetary Evolution 4. Geological Society of America, pp. 269-299. Special Paper 465.

Verbeek, N.A.M., 1996. Occurrence of egg-capping in birds' nests. The Auk 113, 703-705.

Vitek, N.S., 2012. Giant fossil soft-shelled turtles of North America. Palaeontologia Electronica 15, 1-43.

Wang, Q., Wang, X., Zhao, Z., Zhang, J., Jiang, S., 2013. New turtle egg fossil from the Upper Cretaceous of the Laiyang Basin, Shandong Province, China. Anais da Academia Brasileira de Ciências 85, 103-111.

Wendler, J.E., Wendler, I., Rose, T., Huber, B.T., 2012. Using cathodoluminescence spectroscopy of Cretaceous calcareous microfossils to distinguish biogenic from early-diagenetic calcite. Microscopy and Microanalysis 18, 1313-1321.

Winkler, J.D., 2006. Testing phylogenetic implications of eggshell characters in sidenecked turtles (Testudines: Pleurodira). Zoology 109, 127-136.

Zelenitsky, D.K., 1995. Fossil eggs and eggshell fragments form the Oldman Formation (Upper Cretaceous; Campanian), Southern Alberta, Canada. Ph.D. dissertation. University of Calgary, Calgary, Alberta, $151 \mathrm{pp}$.

Zelenitsky, D.K., Therrien, F., Joyce, W.G., Brinkman, D.B., 2008. First fossil gravid turtle provides insight into the evolution of reproductive traits in turtles. Biology Letters 4, 715-718.

\section{Appendix A. Supplementary data}

Supplementary data related to this article can be found at http://dx.doi.org/10. 1016/j.cretres.2016.08.012. 